\title{
Originals
}

\section{Influence of glucose, insulin and sera from diabetic patients on the prostacyclin synthesis in vitro in cultured human endothelial cells}

\author{
S. Aanderud, H. Krane and A. Nordøy \\ Department of Medicine, University Hospital of Tromsø, Tromsø, Norway
}

\begin{abstract}
Summary. The effects of glucose, insulin and sera from Type 1 (insulin-dependent) diabetic patients on the synthesis of prostacyclin in vitro were studied in confluent primary cultures of human endothelial cells. The stable metabolite, 6-keto-prostaglandin $\mathrm{F}_{1 \alpha}$, was measured in growth medium after $24 \mathrm{~h}$ of incubation with endothelial cells in a buffer incubated with the cells for $10 \mathrm{~min}$ on a rocker platform, and in a buffer solution of ruptured cells. Glucose $(11,15,20$ or $25 \mathrm{mmol} / \mathrm{l})$ and glucose $(11 \mathrm{mmol} / \mathrm{l})$ plus insulin $\left(10^{3}, 10^{4}\right.$ or $\left.10^{6} \mathrm{mU} / 1\right)$ in growth medium did not have any effects on the prostacyclin
\end{abstract}

synthesis. The prostacyclin synthesis was significantly reduced in cell cultures incubated with medium supplemented with $10 \%$ serum from patients with Type 1 diabetes $(p<0.01)$ compared with cultures incubated with pooled serum from healthy blood donors. These data suggest that diabetic sera inhibit the prostacyclin synthesis in cultured endothelial cells unrelated to the glucose and insulin levels.

Key words: Diabetes mellitus (Type 1), endothelial cells, glucose, insulin, prostacyclin.
Microangiopathy and vaso-occlusive diseases are well recognized complications of diabetes mellitus. Vascular endothelium generate prostacyclin $\left(\mathrm{PGI}_{2}\right)$, which is a vasodilator and a potent inhibitor of platelet aggregation [1]. Blood vessels from Type 1 (insulin-dependent) diabetic patients and animals have been shown to produce less $\mathrm{PGI}_{2}$ in vitro than vessels from normal subjects [2-4]. It has been suggested that platelet aggregation contributes to the development of macro- and microangiopathy in diabetes $[5,6]$.

The present study was performed in order to test the impact of the main metabolic variables in diabetes mellitus on the synthesis of $\mathrm{PGI}_{2}$, measured as the stable metabolite 6-keto-prostaglandin $\mathrm{F}_{1 \alpha},\left(6-\right.$ keto- $\left.\mathrm{PGF}_{1 \alpha}\right)$, in primary confluent cultures of human endothelial cells.

\section{Materials and methods}

\section{Cell culture}

Endothelial cell monolayer cultures (ECMC) were obtained by preparing cells from human umbilical veins according to the modification of Czervionke et al. [7] of a method described by Jaffe et al. [8]. The cells were cultured in plastic dishes (diameter $35 \mathrm{~mm}$, Falcon Plastics, Oxnard, Calif., USA), in modified medium 199 (MM-199, Gibco Bio-Cult Ltd, Paisley, Scotland) containing glucose (11 mmol/ I) and supplemented with $20 \%$ heat-inactivated fetal calf serum [8]. Confluent primary cultures of endothelial cells were obtained after 4-6 days.

\section{Experimental conditions}

Confluent ECMC were incubated in MM-199 for $24 \mathrm{~h}$ at $37^{\circ} \mathrm{C}$ with addition of: (1) Glucose to final concentration of 15,20 or $25 \mathrm{mmol} / 1$ and supplemented with $10 \%$ fetal calf serum. Control cultures were incubated with addition of urea to isomolar concentrations. (2) Insulin (Actrapid Human, Novo Industries, Copenhagen, Denmark) to final concentration of $10^{3}, 10^{4}$ or $10^{6} \mathrm{mU} / 1$, and supplemented with $10 \%$ fetal calf serum. (3) Serum 10\% from diabetic patients, and with pooled serum from six male and six female blood donors aged $20-40$ years as controls. Blood samples were collected in the morning from 12 fasting patients with Type 1 diabetes, five females and seven males aged 23-64 years (mean 38.6 years) (Table 1). The sera were prepared immediately after collection by centrifugation and kept frozen at $-20{ }^{\circ} \mathrm{C}$ until used in the cell cultures. The sera from diabetic patients had a mean $\pm \mathrm{SD}$ glucose concentration of $11.8 \pm 5.0 \mathrm{mmol} / 1$, triglycerides $2.3 \pm 1.8 \mathrm{mmol} / 1$ and cholesterol $6.4 \pm 2.1 \mathrm{mmol} / 1$. The respective values for the control sera were glucose $4.9 \pm 0.4 \mathrm{mmol} / 1$, triglycerides $1.3 \pm 0.4 \mathrm{mmol} / 1$ and cholesterol $5.9 \pm 0.7 \mathrm{mmol} / 1$. Control cultures in medium containing $10 \%$ fetal calf serum were included in each series of experiments. ECMC were also incubated with $2 \mathrm{ml}$ $100 \%$ sera from diabetic patients or controls for $2 \mathrm{~h}$ at $37^{\circ} \mathrm{C}$.

At the end of the incubation periods ( 24 or $2 \mathrm{~h}$ ) cell morphology was assessed microscopically (Diavert, Leitz, FRG). After washing the ECMC twice with $1.5 \mathrm{ml}$ of a Hepes $/ \mathrm{NaCl}$ solution $(153 \mathrm{mmol} / \mathrm{l}$, $\mathrm{pH} 7.4$ ), the cells were incubated with $2 \mathrm{ml}$ of the same buffer on a rocking platform (Bellco Glass Inc., Vineland, NY, USA) at a rate of $10 \mathrm{cycles} / \mathrm{min}$ at $22^{\circ} \mathrm{C}$ for $10 \mathrm{~min}$. The buffer was pipetted off and the cells were finally disrupted by freezing and thawing three times and dissolved in $1.5 \mathrm{ml} \mathrm{Hepes} / \mathrm{NaCl}$ solution. All test samples were frozen at $-80^{\circ} \mathrm{C}$ without addition of cyclooxygenase inhibitors until analysis. 
Table 1. Clinical data and serum levels of glucose, cholesterol and triglycerides in the diabetic patients

\begin{tabular}{|c|c|c|c|c|c|c|c|c|}
\hline $\begin{array}{l}\text { Patient } \\
\text { number }\end{array}$ & $\begin{array}{l}\text { Age } \\
\text { (years) }\end{array}$ & Sex & $\begin{array}{l}\text { Duration of } \\
\text { diabetes (years) }\end{array}$ & Complications & $\begin{array}{l}\text { Insulin dose } \\
\text { (U/day) }\end{array}$ & $\begin{array}{l}\text { Glucose } \\
(\mathrm{mmol} / \mathrm{l})\end{array}$ & $\begin{array}{l}\text { Cholesterol } \\
(\mathrm{mmol} / \mathrm{l})\end{array}$ & $\begin{array}{l}\text { Triglycerides } \\
(\mathrm{mmol} / \mathrm{l})\end{array}$ \\
\hline 1 & 23 & $\mathbf{F}$ & 11 & None & 32 & 19.9 & 6.1 & 0.8 \\
\hline 2 & 36 & $\mathrm{~F}$ & 24 & Retinopathy & 40 & 9.9 & 10.8 & 2.2 \\
\hline 3 & 36 & $\mathrm{~F}$ & 11 & None & 36 & 8.0 & 5.2 & 1.3 \\
\hline 4 & 24 & $\mathbf{M}$ & 6 & None & 60 & 13.3 & 4.6 & 0.8 \\
\hline 5 & 61 & $\mathbf{M}$ & 5 & None & 24 & 7.8 & 5.9 & 3.0 \\
\hline 6 & 64 & $F$ & 14 & None & 24 & 14.5 & 8.9 & 1.7 \\
\hline 7 & 28 & $\mathbf{M}$ & 23 & None & 48 & 10.1 & 4.6 & 2.1 \\
\hline 8 & 38 & $\mathrm{M}$ & 18 & $\begin{array}{l}\text { Retinopathy } \\
\text { Nephropathy }\end{array}$ & 32 & 3.2 & 9.1 & 7.4 \\
\hline 9 & 32 & M & 10 & None & 68 & 21.0 & 5.4 & 2.6 \\
\hline 10 & 45 & $\mathrm{~F}$ & 1 & None & 24 & 11.3 & 4.9 & 1.3 \\
\hline 11 & 46 & $M$ & 6 & Retinopathy & 32 & 9.2 & 6.3 & 2.9 \\
\hline 12 & 30 & M & 5 & None & 44 & 13.1 & 4.5 & 1.0 \\
\hline
\end{tabular}

Table 2. The recovery of 6-keto-PGF ${ }_{1 \alpha}$ in growth medium supplemented with $10 \%$ serum from fetal calves, human controls or diabetic patients, after $24 \mathrm{~h}$ incubation at $37^{\circ} \mathrm{C}(n=3)$

\begin{tabular}{|c|c|c|c|c|}
\hline \multirow{2}{*}{$\begin{array}{l}\text { Initial con- } \\
\text { centration } \\
\text { of } \\
6 \text {-keto-PGF } 1 \alpha \\
(\mathrm{ng} / \mathrm{ml})\end{array}$} & \multicolumn{4}{|c|}{ 6-keto-PGF ${ }_{1 \alpha}(\mathrm{ng} / \mathrm{ml})$ measured in: } \\
\hline & Medium & $\begin{array}{l}\text { Medium + } \\
\text { fetal } \\
\text { calf } \\
\text { serum }\end{array}$ & $\begin{array}{l}\text { Medium + } \\
\text { control } \\
\text { serum }\end{array}$ & $\begin{array}{l}\text { Medium + } \\
\text { serum from } \\
\text { diabetic } \\
\text { patients }\end{array}$ \\
\hline 12.5 & $12.7 \pm 0.4$ & $11.1 \pm 0.1$ & $9.4 \pm 1.0$ & $9.8 \pm 0.4$ \\
\hline 25 & $29.4 \pm 1.5$ & $28.1 \pm 1.8$ & $29.1 \pm 1.4$ & $27.8 \pm 0.8$ \\
\hline 50 & $59.2 \pm 0.8$ & $50.8 \pm 2.4$ & $57.1 \pm 1.1$ & $54.8 \pm 2.1$ \\
\hline
\end{tabular}

Results are expressed as mean $\pm \mathrm{SD}$

Table 3. The effect of glucose in the growth medium on the production of 6-keto-PGF ${ }_{1 \alpha}$ in endothelial cell cultures (ECMC) during $24 \mathrm{~h}$ of incubation ${ }^{\mathrm{a}, \mathrm{b}}$

\begin{tabular}{|c|c|c|c|c|}
\hline \multirow[t]{2}{*}{ Agent } & \multirow{2}{*}{$\begin{array}{l}\text { No. of } \\
\text { experi- } \\
\text { ments }\end{array}$} & \multicolumn{3}{|c|}{ 6-keto-PGF ${ }_{1 \alpha}(\mathrm{ng} / \mathrm{ml})$ measured in: } \\
\hline & & Medium & $\begin{array}{l}\text { Buffer } \\
\text { incubated } \\
\text { with ECMC }\end{array}$ & $\begin{array}{l}\text { Ruptured } \\
\text { cells }\end{array}$ \\
\hline Glucose $(11 \mathrm{mmol} / \mathrm{l})$ & 8 & $18.3 \pm 7.7$ & $14.0 \pm 8.2$ & $24.1 \pm 9.9$ \\
\hline Glucose $(15 \mathrm{mmol} / \mathrm{l})$ & 10 & $13.6 \pm 3.8$ & $13.4 \pm 6.1$ & $22.1 \pm 7.6$ \\
\hline Control & 10 & $14.0 \pm 3.8$ & $14.3 \pm 6.0$ & $22.0 \pm 7.2$ \\
\hline Glucose $(20 \mathrm{mmol} / \mathrm{l})$ & 4 & $10.9 \pm 0.4$ & $12.9 \pm 7.6$ & $21.8 \pm 9.4$ \\
\hline Control & 4 & $11.4 \pm 2.8$ & $13.3 \pm 8.3$ & $23.3 \pm 6.7$ \\
\hline Glucose $(25 \mathrm{mmol} / \mathrm{l})$ & 8 & $15.2 \pm 4.7$ & $14.7 \pm 5.6$ & $21.0 \pm 6.3$ \\
\hline Control & 8 & $15.8 \pm 8.0$ & $14.7 \pm 6.0$ & $20.4 \pm 6.9$ \\
\hline
\end{tabular}

${ }^{a}$ Results are expressed as mean $\pm \mathrm{SD}$; ${ }^{b}$ The control cultures were incubated with medium added urea to obtain isomolality

Table 4. Effect of insulin on the production of 6-keto- $\mathrm{PFG}_{1 \alpha}$ in endothelial cell cultures (ECMC) after $24 \mathrm{~h}$ of incubation with growth medium containing glucose $(11 \mathrm{mmol} / \mathrm{l})$ and $10 \%$ heat-inactivated fetal calf serum

\begin{tabular}{|c|c|c|c|c|}
\hline \multirow[t]{2}{*}{ Insulin (mU/1) } & \multirow{2}{*}{$\begin{array}{l}\text { No. of } \\
\text { experi- } \\
\text { ments }\end{array}$} & \multicolumn{3}{|c|}{ 6-keto-PGF ${ }_{1 \alpha}(\mathrm{ng} / \mathrm{ml})$ measured in: } \\
\hline & & Medium & $\begin{array}{l}\text { Buffer } \\
\text { incubated } \\
\text { with ECMC }\end{array}$ & $\begin{array}{l}\text { Ruptured } \\
\text { cells }\end{array}$ \\
\hline 0 & 10 & $15.9 \pm 8.0$ & $14.5 \pm 7.8$ & $23.9 \pm 13.4$ \\
\hline $10^{3}$ & 10 & $12.8 \pm 4.8$ & $14.7 \pm 6.1$ & $25.3 \pm 9.0$ \\
\hline $10^{4}$ & 4 & $20.1 \pm 8.1$ & $17.0 \pm 9.8$ & $34.9 \pm 5.0$ \\
\hline $10^{6}$ & 12 & $11.1 \pm 5.1$ & $15.6 \pm 6.9$ & $26.0 \pm 12.9$ \\
\hline
\end{tabular}

Results are expressed as mean $\pm \mathrm{SD}$
- Table 5. Influence of 10\% human sera from controls and diabetic patients on the production of 6-keto-PGF $F_{1 \alpha}$ in endothelial cell cultures (ECMC) during $24 \mathrm{~h}$ of incubation

\begin{tabular}{|c|c|c|c|c|}
\hline \multirow[t]{2}{*}{ Serum from } & \multirow{2}{*}{$\begin{array}{l}\text { No. of } \\
\text { experi- } \\
\text { ments }\end{array}$} & \multicolumn{3}{|c|}{ 6-keto-PGF ${ }_{1 \alpha}(\mathrm{ng} / \mathrm{ml})$ measured in: } \\
\hline & & Medium & $\begin{array}{l}\text { Buffer } \\
\text { incubated } \\
\text { with ECMC }\end{array}$ & $\begin{array}{l}\text { Ruptured } \\
\text { cells }\end{array}$ \\
\hline Controls & 8 & $19.3 \pm 7.6$ & $12.2 \pm 5.3$ & $15.8 \pm 4.3$ \\
\hline Diabetic patients & 12 & $12.7 \pm 4.1^{\mathrm{a}}$ & $11.9 \pm 3.8$ & $14.4 \pm 3.4$ \\
\hline
\end{tabular}

Results are expressed as mean \pm SD. Significance of differences compared to control human sera; ${ }^{a} p<0.001$

\section{Analyses}

6-keto-PGF P $_{1 \alpha}$ was determined by radioimmunoassay as described by Salmon [9] with one modification: the incubation time with dextrancoated charcoal was $10 \mathrm{~min}$. Antibody against 6 -keto-PGF $\mathrm{PF}_{1 \alpha}$ and the 6-keto-PGF $1 \alpha$ standards were kindly donated by Dr. I.A.Salmon, Wellcome Research Laboratories, Beckenham, Kent, UK. ${ }^{3} \mathrm{H}-6$-keto$\mathrm{PGF}_{1 \alpha}$ was purchased from New England Nuclear, Boston, Mass., USA. The specificity and sensitivity (detection limit $50-100 \mathrm{pg} / \mathrm{ml}$ ) of the method has recently been described [10]. The $\mathrm{PGI}_{2}$ synthesis from ECMC was estimated by measuring 6-keto-PGF ${ }_{1 \alpha}$ in the growth medium, the stimulated cellular release after $10 \mathrm{~min}$ of rocking and in the buffer solution of disrupted cells. 6-keto-PGF $1 \alpha$ was also measured in the serum from diabetic patients and controls. In preliminary experiments, 6-keto-PGF PG $_{1 \alpha}$ (Sigma Chemical Co., St. Louis, USA) was incubated in final concentrations of 12.5, 25 and $50 \mathrm{ng} / \mathrm{ml}$ in MM-199 without and with supplement of $10 \%$ fetal calf serum, $10 \%$ control human serum or $10 \%$ serum from diabetic patients for $24 \mathrm{~h}$ at $37^{\circ} \mathrm{C}$. At the end of the incubation period no significant differences in the recovery between the different incubation media were observed (Table 2).

Serum glucose was measured by the hexokinase method ("Gluco Quant", Boehringer Mannheim, Mannheim, FRG). The coefficient of variation was $3.3 \%$. Serum cholesterol was measured according to the method of Trinder [11]. The coefficient of variation was $1.4 \%$. Serum triglycerides were measured by the fully enzymatic kit from Boehringer Mannheim (combined lipase and glycerolkinase reaction). The coefficient of variation was $6.4 \%$.

\section{Statistics}

Two-tailed Student's t-test for paired and unpaired data was used for the statistical evaluation of the results. The results were expressed as mean $\pm \mathrm{SD}$. 


\section{Results}

The in vitro synthesis of 6-keto-PGF ${ }_{1 \alpha}$ in ECMC was not influenced by varying the glucose concentrations in medium (MM-199) from 11 to $25 \mathrm{mmol} / 1$ or by increasing osmolality in the medium by addition of urea (Table 3). Incubations of ECMC with medium containing glucose $(11 \mathrm{mmol} / \mathrm{l})$ and insulin in final concentrations of $10^{3}, 10^{4}$ or $10^{6} \mathrm{mU} / 1$ did not have any significant effects on the synthesis of 6-keto-PGF ${ }_{1 \alpha}$ (Table 4). Incubation of ECMC with $100 \%$ serum from patients or controls for $2 \mathrm{~h}$ or with medium supplemented with $10 \%$ serum from diabetic patients for $24 \mathrm{~h}$ did not change the cell morphology or density.

The 6-keto-PGF ${ }_{1 \alpha}$ production from ECMC after $24 \mathrm{~h}$ of incubation with growth medium containing $10 \%$ serum from each of the blood donors was similar whether the serum was prepared from males or females. The sera were therefore pooled and used as controls. Incubation of the cells for $24 \mathrm{~h}$ with medium containing $10 \%$ serum from diabetic patients gave a significantly lower medium concentration of 6-keto-PGF $1 \alpha$ than incubations with pooled control serum $(p<0.01)$ (Table 5). Detectable amounts of 6-keto-PGF $\mathrm{PG}_{1 \alpha}(>$ $0.05 \mathrm{ng} / \mathrm{ml}$ ) were not found in the sera from diabetic patients or in the control sera before incubation with endothelial cells.

The release of 6-keto-PGF ${ }_{1 \alpha}$ from $\mathrm{ECMC}$ was not influenced by incubation for $2 \mathrm{~h}$ with $100 \%$ serum from diabetic patients $(6.9 \pm 6.0 \mathrm{ng} / \mathrm{ml})$ compared with control sera $(5.0 \pm 4.3 \mathrm{ng} / \mathrm{ml})$.

There was no correlation between the reduction in 6-keto-PGF $\mathrm{P}_{1 \alpha}$ synthesis in endothelial cells incubated with serum from diabetic patients and the degree of hyperglycaemia or the concentration of serum total cholesterol and triglycerides. Furthermore, no correlation could be established between the reduction in 6-keto$\mathrm{PGF}_{1 \alpha}$ production and the duration of diabetes, the occurrence of complications or the dosage of insulin used in the individual patient.

\section{Discussion}

The present study demonstrated that serum from diabetic patients contained one or more substances which inhibited the synthesis of $\mathrm{PGI}_{2}$ (measured as the stable metabolite 6-keto-PGF $1 \alpha$ ) in cultured human endothelial cells. This is quite in accordance with a previous report by Paton et al. [12] about diminished synthesis of $\mathrm{PGI}_{2}$ by endothelial cells cultured in medium containing serum from diabetic patients with proliferative retinopathy. We did not, however, find any effect on the in vitro prostacyclin synthesis from ECMC either by increasing the glucose or the insulin concentrations in the growth medium. It should be stressed that we only used glucose concentrations in the hyperglycaemic range $(11-25 \mathrm{mmol} / \mathrm{l})$. A recent study [13] has, however, shown that a glucose concentration ranging from 5.6 to $22.4 \mathrm{mmol} / 1$ did not modify $\mathrm{PGI}_{2}$ production in cultured human endothelial cells. Our results seem to be in conflict with the study of Jeremy et al. [14], which demonstrated a stimulatory effect on the synthesis of $\mathrm{PGI}_{2}$ in vitro from rat aortic rings incubated with glucose at concentrations between 10 and $35 \mathrm{mmol} / \mathrm{l}$, while insulin inhibited the $\mathrm{PGI}_{2}$ synthesis at concentrations 10 and $50 \mathrm{mU} / 1$ by $10 \%$ and $25 \%$, respectively. Species differences, shorter incubation period and use of much lower concentrations of insulin without glucose supplement to the medium may explain the differences. When they tested the insulin effect in the presence of glucose $(10 \mathrm{mmol} / \mathrm{l})$ a stimulatory effect of insulin $(10 \mathrm{mU} / 1)$ was found. An inhibitory effect of insulin in concentrations of $2.5,0.5$ and $0.25 \mathrm{mU} / 1$ on the synthesis of $\mathrm{PGI}_{2}$ from rat aortic ring after $1 \mathrm{~h}$ of incubation in buffer containing glucose $(2.8 \mathrm{mmol} / \mathrm{l})$ has recently been reported [15].

Our study suggests that the reduction in synthesis of $\mathrm{PGI}_{2}$ in vitro from ECMC exposed to sera from diabetic patients is confined to one or more unidentified serum factors, independent of glucose and insulin. Soluble immune complexes from diabetic patients have been found to enhance platelet aggregation [16,17], and a pathogenetic role for soluble immune complexes in the development of diabetic angiopathy has been postulated [18].

Lipid and lipoprotein abnormalities are integrated parts of the metabolic derangements in diabetes [19-21]. Decreased synthesis of $\mathrm{PGI}_{2}$ from ECMC by high concentrations of LDL in the growth medium has been found previously [22]. However, the total cholesterol levels in all except 3 sera from the diabetic patients were within normal limits, while 6 of 12 patients had elevated triglyceride levels. Furthermore, no correlation could be established between the serum cholesterol or triglyceride concentrations and the inhibitory effects on $\mathrm{PGI}_{2}$ production in vitro. Increased levels of plasma FFA have been reported in poorly controlled diabetic patients [23]. The concentration and composition of FFA were not determined in the present study. As, however, no inhibitory effects were observed when the cell cultures were incubated with $100 \%$ sera from diabetic patients for $2 \mathrm{~h}$, this possibility also seems unlikely.

In a previous study, Arbogast et al. [24] found a toxic effect of sera from diabetic rats on cultured porcine aortic endothelial cells. We were unable by morphologic criteria to demonstrate a similar effect in our cell cultures.

In conclusion, we have shown that sera from diabetic patients inhibit the prostacyclin synthesis in cultured human endothelial cells. This effect seems unrelated to the glucose and insulin levels. If a similar reduced synthesis of prostacyclin in the vascular wall also occurs in vivo, it may contribute to the development of vascular disease in diabetes. 
Acknowledgements. The skilled technical assistance of B Svensson and C Lowery and the secretarial assistance by LN Enoksen and E Andersen is greatly appreciated. This study was supported in part by The Norwegian Council on Cardiovascular Research.

\section{References}

1. Moncada S, Vane JR (1979) Arachidonic acid metabolites and the interactions between platelets and blood-vessel walls. N Engl J Med 300: 1142-1147

2. Johnson M, Harrison HE, Raftery AT, Elder JB (1979) Vascular prostacyclin may be reduced in diabetes in man. Lancet 1: 325-326

3. Silberbauer K, Schernthaner G, Sinzinger H, Piza-Katzer H, Winter M (1979) Decreased vascular prostacyclin in juvenile-onset diabetes. N Engl J Med 300: 366-367 (letter)

4. Harrison HE, Reece AH, Johnson M (1978) Decreased vascular prostacyclin in experimental diabetes. Life Sci 23:351-356

5. Colwell JA, Halushka PV, Sarji KE, Lopes-Virella MF, Sagel J (1979) Vascular disease in diabetes. Pathophysiological mechanisms and therapy. Arch Intern Med 139: 225-230

6. Tindall H, Paton RC, Zuzel M, McNicol GP (1981) Platelet lifespan in diabetics with and without retinopathy. Thrombosis Res 21: 641-648

7. Czervionke RL, Hoak JC, Fry GL (1978) Effects of aspirin on thrombin-induced adherence of platelets to cultured cells from the blood vessel wall. J Clin Invest 62: 847-856

8. Jaffe EA, Nachman RL, Becker CG, Minick CR (1973) Culture of human endothelial cells derived from umbilical veins. Identification by morphologic and immunologic criteria. J Clin Invest 52 : $2745-2756$

9. Salmon JA (1978) A radioimmunoassay for 6-keto-prostaglandin $\mathrm{F}_{1 \alpha}$. Prostaglandins 15:383-399

10. Brox JH, Nordøy A (1983) The effect of polyunsaturated fatty acids on endothelial cells and their production of prostacyclin, thromboxane and platelet inhibitory activity. Thromb Haemost 50: $762-767$

11. Trinder $P$ (1969) Determination of blood glucose using an oxidaseperoxidase system with a non-carcinogenic chromogen. J Clin Pathol 22: 158-161

12. Paton RC, Guillot R, Passa Ph, Canivet J (1982) Prostacyclin production by human endothelial cells cultured in diabetic serum. Diabete Metab 8: 323-328
13. Weimann BJ, Lorch E, Baumgartner HR (1984) High glucose concentrations do not influence replication and prostacyclin release of human endothelial cells. Diabetologia 27: 62-63 (Letter)

14. Jeremy JY, Mikhailidis DP, Dandona P (1983) Simulating the diabetic environment modifies in vitro prostacyclin synthesis. Diabetes 32: $217-221$

15. Lasché EM, Larson RE (1982) Interaction of insulin and prostacyclin production in the rat. Diabetes 31: 454-458

16. Colwell JA, Van Zile J, Kilpatrick JM, Nair PMG, Virella G (1981) Plasma factors and platelet aggregation in diabetes mellitus. Horm Metab Res 11: 1-6

17. Van Zile J, Kilpatrick M, Lamins J, Sagel J, Colwell J, Virella G (1981) Platelet aggregation and release of ATP after incubation with soluble immune complexes purified from the serum of diabetic patients. Diabetes 30: $575-579$

18. Di Mario U, Iavicoli M, Andreani D (1980) Circulating immune complexes in diabetes. Diabetologia 19:89-92

19. Nikkilä EA, Hormila $P(1978)$ Serum lipids and lipoproteins in insulin-treated diabetes. Demonstration of increased high density lipoprotein concentrations. Diabetes 27: 1078-1086

20. Sosenko JM, Breslow JL, Olli S, Miettinen OS, Gabbay KH (1980) Hyperglycemia and plasma lipid levels. A prospective study of young insulin-dependent diabetic patients. $N$ Engl $\mathbf{J}$ Med 302: 650-654

21. Lopes-Virella MF, Wohltmann HJ, Loadholt CB, Buse MG (1981) Plasma lipids and lipoproteins in young insulin-dependent diabetic patients: relationship with control. Diabetologia 21:216-223

22. Nordøy A, Svensson B, Wiebe D, Hoak JC (1978) Lipoproteins and the inhibitory effect of human endothelial cells on platelet function. Circulation Res 43: 527-534

23. Johnston DG, Alberti KGMM (1982) Hormonal control of ketone body metabolism in the normal and diabetic state. Clin Endocrinol Metab 11:329-361

24. Arbogast BW, Lee GM, Raymans TL (1982) In vitro injury of porcine aortic endothelial cells by very-low-density lipoproteins from diabetic rat serum. Diabetes 31: 593-599

Received: 3 September 1984

and in revised form: 20 June 1985

Dr. Sylvi Aanderud

Department of Medicine

Haukeland Hospital

University of Bergen

N-5016 Bergen, Norway 